\title{
Keluhan Utama pada Keterlambatan Perkembangan Umum di Klinik Khusus Tumbuh Kembang RSAB Harapan Kita
}

\author{
Anna Tjandrajani, * Attila Dewanti, * Amril A. Burhany, * Joanne Angelica Widjaja** \\ ${ }^{*}$ Kelompok Kerja Neurologi Anak, Rumah Sakit Anak dan Bunda Harapan Kita, Jakarta \\ ** S1 Profesi, Fakultas Kedokteran Universitas Indonesia
}

\begin{abstract}
Latar belakang. Keterlambatan perkembangan umum (KPU) pada pasien dengan fisik normal dan tidak ada riwayat penyakit berat atau penyakit penyerta lainnya seringkali tidak terdeteksi sejak dini. Keluhan utama orang tua seringkali menjadi prediktor mengenai keterlambatan atau gangguan perkembangan pada anak. Tidak jarang klinisi melakukan stimulasi dan intervensi hanya berdasarkan keluhan utama tanpa menilai perkembangan lain dan hal tersebut akan menyebabkan tata laksana yang tidak optimal.

Tujuan. Mengetahui sebaran keluhan utama dan area yang mengalami keterlambatan.

Metode. Desain penelitian deskriptif retrospektif dari rekam medik pada pasien baru berusia 0-5 tahun dengan KPU di Klinik Khusus Tumbuh Kembang (KKTK) RSAB Harapan Kita, pada Januari 2008 sampai dengan Desember 2009.

Hasil. Terdapat 187 (30,9\%) pasien baru dengan keterlambatan perkembangan umum, dan 94 (50,3\%) kasus adalah KPU tanpa penyakit penyerta. Keluhan utama pasien KPU tanpa penyakit penyerta adalah gangguan bicara 46,8\%, perkembangan gerak terlambat 30,9\%, dan tanpa keluhan $12,8 \%$.

Kesimpulan. Keluhan utama terbanyak pasien KPU tanpa penyakit penyerta adalah keterlambatan atau gangguan dalam perkembangan bicara anak. Keluhan utama orang tua harus ditindaklanjuti dan dapat menjadi prediktor perkembangan anak. Sari Pediatri 2012;13(6):373-77.
\end{abstract}

Kata kunci: keterlambatan perkembangan umum, keluhan utama, keterlambatan bicara

\footnotetext{
Alamat korespondensi:

Dr. Anna Tjandrajani,, SpA(K). Staf Divisi Neurologi Anak RS Anak dan Bunda Harapan Kita Jakarta, Jl. Letjen S. Parman Kav. 87, Slipi. Telp. (021) 5668284 .
}

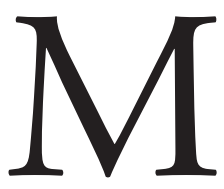

asalah perkembangan pada anak khususnya keterlambatan perkembangan umum sering dijumpai dan membutuhkan evaluasi dari aspek neurologi anak. Oleh karena itu diagnosis awal dan pengenalan tanda-tanda gangguan perkembangan sangatlah penting. Keterlambatan perkembangan 
umum (KPU) atau global developmental delay $(G D D)$ adalah bagian dari ketidakmampuan mencapai perkembangan sesuai usia, dan didefinisikan sebagai keterlambatan dalam dua bidang atau lebih perkembangan motor kasar/motor halus, bicara/ berbahasa, kognisi, personal/sosial dan aktifitas sehari-hari. Istilah ini digunakan bagi anak yang berusia kurang dari lima tahun. Istilah KPU menggambarkan keadaan klinis yang berhubungan dengan berbagai penyebab dan ketidaksesuaian perkembangan adaptasi serta belajar pada kelompok umur tertentu. ${ }^{1-5}$ Prevalensi yang sebenarnya keterlambatan perkembangan umum tidak diketahui dengan pasti. Diperkirakan 5\%-10\% anak mengalami masalah keterlambatan perkembangan. ${ }^{1-3}$ Keterlambatan perkembangan umum merupakan bagian dari keterlambatan perkembangan, dengan prevalensi $1 \%-3 \% .^{3}$

Penyebab keterlambatan perkembangan umum yang terbanyak adalah kelainan kromosom dan malformasi otak, tetapi banyak juga penyebab lainnya. Keterlambatan perkembangan umum pada pasien dengan kelainan fisik nyata atau riwayat penyakit berat dapat dianalisis/dinilai lebih dini, namun hal ini lebih sulit pada pasien dengan fisik normal dan tidak ada riwayat penyakit berat atau penyakit penyerta lainnya. Bila stimulasi dan intervensi dilakukan hanya berdasarkan keluhan utama tanpa menilai perkembangan lain, maka tata laksana KPU menjadi tidak optimal, dan keluhan utama ini seringkali tidak selalu mencerminkan keadaan sebenarnya. Hal ini mungkin dipengaruhi oleh banyak faktor, salah satunya pengetahuan orangtua tentang perkembangan anak. Oleh karena itu keluhan tersebut menjadi sangat penting untuk diperhatikan, dan harus dievaluasi lebih lanjut.

Tujuan penelitian untuk mengetahui sebaran keluhan utama dan kejadian keterlambatan area perkembangan yang ditemukan seperti motorik kasar, motorik halus, bicara reseptif dan ekspresif, kognisi, dan sosialisasi pada pasien baru KPU tanpa penyakit penyerta di Klinik Khusus Tumbuh Kembang (KKTK) RSAB Harapan Kita. Melalui hasil penelitian diharapkan dapat menjadi wacana bahwa keluhan orangtua tidak dapat diabaikan tetapi harus dicermati dan dievaluasi secara objektif. Dengan demikian intervensi dan stimulasi dini lebih terarah dan sesuai gangguan area keterlambatan yang ditemukan.

\section{Metode}

Subjek penelitian adalah pasien baru berusia kurang dari 5 tahun dengan keterlambatan perkembangan umum tanpa penyakit penyerta, yang dinilai secara retrospektif dari data rekam medis di KKTK RSAB Harapan Kita dari bulan Januari 2008 sampai dengan Desember 2009. Pada rekam medik tercantum data keluhan utama (orangtua/wali yang membawa anak berkunjung), perujuk, dan diagnosis atau analisis dari perujuk, riwayat penyakit (termasuk riwayat kehamilan, persalinan, perinatal, dan postnatal), pemeriksaan fisik umum normal, pemeriksaan neurologis dalam batas normal serta penilaian perkembangan yang lengkap, tanpa penyakit penyerta. Semua pasien yang diperiksa telah menjalani penilaian dan evaluasi yang dilakukan dalam rangka menegakkan diagnosis oleh dokter spesialis anak yang mendalami tumbuh kembang anak, neurodevelopment dan psikolog perkembangan anak pada waktu yang bersamaan. Diagnosis keterlambatan perkembangan umum ditegakkan bila pasien mempunyai keterlambatan di dalam dua area perkembangan atau lebih dengan rentang keterlambatan lebih dari 3 bulan dibandingkan usianya untuk masing-masing area perkembangan. Pengolahan data dilakukan secara deskriptif dan dengan menggunakan SPSS 11.5.

\section{Hasil}

Di antara 604 pasien baru di KKTK yang dievaluasi didapatkan 187 (30,9\%) pasien dengan keterlambatan perkembangan umum, 93 kasus (49,7\%) di antaranya mempunyai sebab yang jelas kelainan kongenital, mikrosefali, makrosefali, epilepsi, gangguan sensori integrasi, kejang demam, ensefalitis, cerebral palsy, hipotiroid kongenital, sindrom down, riwayat asfiksia, dan ADHD. Sisanya $94(50,3 \%)$ tanpa penyakit penyerta, terdiri dari 62 (66\%) laki-laki dan 32 orang perempuan.

Dari Tabel 1 tertera bahwa 44 (46,81\%) pasien datang dengan keluhan gangguan dalam bicara. Gangguan dalam bicara meliputi pasien belum bisa bicara, terlambat bicara, bicara belum lancar, bicara tidak jelas. Keluhan belum bisa tengkurap, duduk, merangkak, berdiri atau berjalan dirangkum dalam kelompok keluhan perkembangan gerak terlambat, pada penelitian ini ditemukan 29 (30,85\%) kasus. Sembilan $(9,5 \%)$ kasus datang dengan keluhan anak 
belum bisa apa-apa, daya tangkap anak kurang, anak cuek, tumbuh kembang yang kurang dan dengan kesulitan belajar. Secara umum pendidikan ibu cukup baik, 68,1\% berpendidikan tinggi (lulusan akademi dan perguruan tinggi), dan 31,9\% berpendidikan menengah menengah (lulusan sekolah menengah pertama dan sekolah menengah atas).

Dua belas kasus yang datang tanpa keluhan termasuk pasien rujukan dokter umum dan dokter spesialis anak. Dari penelitian didapatkan hanya 31 (33\%) yang merupakan rujukan, sisanya 63 (67\%) datang tanpa rujukan atau atas keinginan orangtua/wali. Pada 31 rujukan 6 kasus di antaranya dirujuk dengan diagnosis keterlambatan perkembangan umum.

Pada Tabel 2 tertera bahwa keterlambatan terutama terdapat pada usia 13-36 bulan.
Tabel 3 merupakan rangkuman sebaran hasil evaluasi menunjukan keterlambatan perkembangan yang didapat dua bidang atau lebih dengan 34 $(36,2 \%)$ kasus mengalami keterlambatan dalam 5 bidang perkembangan dan 29 (30,9\%) mengalami keterlambatan pada semua bidang.

\section{Pembahasan}

Di antara semua pasien baru yang dievaluasi di Klinik Khusus Tumbuh Kembang (KKTK) RSAB Harapan Kita pada tahun 2008-2009 didapat 30,9\% kasus dengan keterlambatan perkembangan umum, merupakan kasus terbanyak yang ditemukan. Pada penelitian Shevell ${ }^{7}$ dan Delgado ${ }^{8}$ KPU menempati

Tabel 1. Sebaran keluhan utama pasien menurut pendidikan ibu dan usia anak

\begin{tabular}{|c|c|c|c|c|c|c|c|}
\hline \multirow[b]{3}{*}{ Keluhan } & \multicolumn{6}{|c|}{ Pendidikan ibu } & \multirow{3}{*}{ Total } \\
\hline & \multicolumn{3}{|c|}{ Pendidikan menengah } & \multicolumn{3}{|c|}{ Pendidikan tinggi } & \\
\hline & $\begin{array}{c}0-12 \\
\text { bulan }\end{array}$ & $\begin{array}{l}13-36 \\
\text { bulan }\end{array}$ & $\begin{array}{c}>36 \\
\text { bulan }\end{array}$ & $\begin{array}{c}0-12 \\
\text { bulan }\end{array}$ & $\begin{array}{l}13-36 \\
\text { bulan }\end{array}$ & $\begin{array}{l}>36 \\
\text { bulan }\end{array}$ & \\
\hline Gangguan bicara, $\mathrm{n}(\%)$ & $0(0)$ & $8(8,5)$ & $6(6,4)$ & $0(0)$ & $16(17,0)$ & $14(14,9)$ & $44(46,8)$ \\
\hline Perkembangan gerak terlambat, $\mathrm{n}(\%)$ & $0(0)$ & $8(8,5)$ & $0(0)$ & $11(11,7)$ & $9(9,6)$ & $1(1,1)$ & $29(30,9)$ \\
\hline Tidak ada keluhan, n(\%) & $2(2,1)$ & $2(2,1)$ & $1(1,1)$ & $4(4,2)$ & $1(1,1)$ & $2(2,1)$ & $12(12,8)$ \\
\hline Keluhan lainnya, n(\%) & $0(0)$ & $2(2,1)$ & $1(1,1)$ & $5(5,3)$ & $1(1,1)$ & $0(0)$ & $9(9,5)$ \\
\hline
\end{tabular}

Tabel 2. Sebaran keterlambatan perkembangan hasil evaluasi menurut usia anak

\begin{tabular}{lcccc}
\hline \multirow{2}{*}{ Keterlambatan } & \multicolumn{3}{c}{ Usia (bulan) } & \multirow{2}{*}{ Total } \\
\cline { 2 - 4 } & $0-12$ & $13-36$ & $>36$ & \\
\hline Motor kasar & $12(12,8)$ & $45(47,9)$ & $23(24,5)$ & $80(85,1)$ \\
Motor halus & $10(10,6)$ & $45(47,9)$ & $25(26,6)$ & $80(85,1)$ \\
Bicara ekspresif & $7(7,4)$ & $43(45,7)$ & $24(25,5)$ & $74(78,7)$ \\
Bicara reseptif & $0(0)$ & $22(23,4)$ & $21(22,3)$ & $43(45,7)$ \\
Sosialisasi & $8(8,5)$ & $39(41,5)$ & $24(25,5)$ & $71(75,5)$ \\
Kognisi & $7(7,4)$ & $38(40,4)$ & $24(25,5)$ & $69(73,4)$ \\
\hline
\end{tabular}

Tabel 3. Sebaran rangkuman jumlah area/bidang keterlambatan berdasarkan usia anak

\begin{tabular}{lcccc}
\hline \multirow{2}{*}{ Jumlah area keterlambatan (bidang) } & \multicolumn{3}{c}{ Usia (bulan), $\mathrm{n}(\%)$} \\
\cline { 2 - 4 } & $0-12$ & $12-36$ & $>36$ & \\
\hline $2, \mathrm{n}(\%)$ & $13(13,8)$ & $1(1,1)$ & $0(0)$ & $14(14,9)$ \\
$3, \mathrm{n}(\%)$ & $3(3,2)$ & $1(1,1)$ & $1(1,1)$ & $5(5,3)$ \\
$4, \mathrm{n}(\%)$ & $3(3,2)$ & $9(9,6)$ & $0(0)$ & $12(12,8)$ \\
$5, \mathrm{n}(\%)$ & $3(3,2)$ & $25(26,6)$ & $6(6,4)$ & $34(36,2)$ \\
Semua bidang, n (\%) & $0(0)$ & $11(11,7)$ & $18(19,1)$ & $29(30,9)$ \\
\hline Total & $22(23,4)$ & $47(50)$ & $25(26,6)$ & $94(100)$ \\
\hline
\end{tabular}


urutan tiga dari diagnosis terbanyak yang didapatkan pada anak-anak yang memiliki gangguan dalam tumbuh kembang.

Hasil penelitian di klinik tumbuh kembang anak dan remaja RS dr. Soetomo pada tahun 2005, KPU menempati diagnosis utama pasien (29,8\%). ${ }^{9}$ Meskipun hasil penelitian kami tidak mencerminkan angka kejadian secara umum di masyarakat, tetapi dapat menggambarkan pentingnya diketahui lebih lanjut mengenai KPU dan faktor-faktor yang berperan di dalamnya.

Separuh dari kasus dibawa untuk konsultasi pada usia 13-36 bulan, menggambarkan angka diagnosis dini KPU, cukup tinggi. Diagnosis dini membantu dilakukan tindakan dini berbagai program, seperti stimulasi motor kasar dan halus, wicara, kognisi serta edukasi orangtua agar tumbuh kembang anak optimal. Diagnosis awal pada anak dengan KPU akan memberikan hasil yang lebih baik di kemudian hari. ${ }^{1,4,5}$

Sebaran responden berdasarkan jenis kelamin didapatkan laki-laki (66\%) lebih banyak dibandingkan dengan perempuan $(34 \%)$, menunjukkan relatif sama dengan penelitian lain yang menyatakan bahwa kebanyakan pasien KPU adalah laki-laki. ${ }^{6-8}$ Sebaran responden juga sesuai dengan jumlah penduduk menurut SUPAS 2005 yang menunjukkan kelompok anak usia 0-4 tahun di Indonesia, jumlah anak laki-laki lebih banyak dibandingkan anak perempuan. ${ }^{10}$

Tigapuluh tiga persen kasus merupakan rujukan dokter, sisanya datang atas kemauan orangtua/ walinya. Penelitian lain juga menunjukkan hal yang sama, hanya didapatkan sedikit anak yang dirujuk oleh dokter. ${ }^{7}$ Tingkat pendidikan ibu setingkat perguruan tinggi, $(68,1 \%)$ mendukung dengan bahwa perhatian orangtua pada perkembangan anak diduga berhubungan dengan tingkat pendidikan orangtua. Penelitian lain mengatakan bahwa pendidikan ibu berperan dalam faktor yang menentukan perkembangan anak. Pendidikan ibu mempengaruhi stimulasi yang diberikan kepada anak, cara mendidik dan cara untuk mengasuh anak, serta bagaimana cara memecahkan masalah. Ibu dengan pendidikan yang rendah meningkatkan risiko keterlambatan perkembangan pada anak. ${ }^{8,11-12}$

Orang tua dengan pendidikan tinggi dan status sosial tinggi mempunyai kesempatan lebih besar untuk mendapatkan informasi serta pelayanan kesehatan. Pada umumnya orang tua dengan pendidikan tinggi lebih sadar apabila terdapat gangguan dalam perkembangan anak mereka. Meskipun demikian pengetahuan tentang perkembangan anak ternyata belum diketahui secara menyeluruh, hal ini tampak dari keluhan utama tertinggi adalah gangguan bicara 44 kasus $(46,8 \%)$. Dari riwayat perjalanan penyakit pada rekam medik tidak didapat keluhan tambahan selain keluhan utama. Tercatat $12,8 \%$ pasien tanpa keluhan adalah rujukan dari dokter umum dan dokter anak, menandakan bahwa kewaspadaan dokter dalam perkembangan anak sudah cukup tinggi.

Hasil evaluasi perkembangan memperlihatkan $85,1 \%$ keterlambatan perkembangan motor kasar dan halus, diikuti keterlambatan bicara ekspresif, sosialisasi, kognisi, dan bicara reseptif. Meskipun keluhan utama terbanyak adalah gangguan bicara, ternyata keterlambatan yang ditemukan tidak hanya satu area perkembangan, yaitu dua area perkembangan 14 kasus $(14,9 \%)$ dari 6 keterlambatan perkembangan yang dievaluasi dan sisanya lebih dari dua area. Hampir seluruh kasus yang berusia kurang dari 12 bulan mempunyai keterlambatan area perkembangan motorik.

Dapat diperkirakan bahwa orang tua lebih tanggap terhadap gangguan perkembangan motorik untuk kelompok usia di bawah 12 bulan dan gangguan bicara ekspresif pada kelompok usia di atas 12 bulan dibandingkan dengan gangguan perkembangan lainnya. Faktor yang mempengaruhi perkembangan berbicara dan berbahasa di antaranya adalah perkembangan fisik dan mental anak, dan juga pengaruh dari lingkungan serta bagaimana respon anak terhadap sekelilingnya. Keterlambatan bicara dapat merupakan gejala dari berbagai penyakit seperti retardasi mental, kelainan pada pendengaran, gangguan dalam berbahasa, autis, afasia, dan keterlambatan dalam perkembangan. ${ }^{13,14}$ Dalam pemeriksaan anak dengan keluhan gangguan bicara diharapkan dokter juga memeriksa perkembangan kognitif, neurologis, fisik serta perkembangan anak lainnya. Hal tersebut sangat penting karena gangguan bicara dapat bersifat sekunder dari kelainan perkembangan lainnya atau bersamaan dengan kelainan lain. Perhatian awal orang tua mungkin adalah pada keterlambatan bicara, namun evaluasi perkembangan menunjukkan terdapat keterlambatan dalam reseptif, memecahkan masalah serta keterlambatan dalam motorik. ${ }^{14}$

Keluhan orang tua mengenai perkembangan anak merupakan indikator yang sangat penting untuk menilai perkembangan. Keluhan orang tua dapat berguna untuk 
membantu deteksi dini kelainan perkembangan anak. Melalui deteksi dini, dapat dilakukan intervensi dini. Dari beberapa penelitian dilaporkan bahwa 70\%-80\% perkembangan anak dapat diidentifikasi oleh keluhan orang tua. Keluhan perkembangan bicara anak cukup sensitif untuk menilai keterlambatan perkembangan anak. ${ }^{15,16}$ Penelitian yang dilakukan oleh Chen ${ }^{16}$ menunjukkan sensitivitas yang tinggi dari keluhan orang tua mengenai perkembangan bicara, motorik dan perilaku anak dalam menentukan keterlambatan anak. Perkembangan bicara, motorik, dan perilaku jelas dan lebih mudah terdeteksi oleh orang tua atau orang yang merawat anak. Namun terdapat beberapa orang tua yang tidak memiliki pengetahuan tentang perkembangan anak secara normal.

Untuk mendapatkan faktor yang mempengaruhi perkembangan anak, seperti status sosial, ekonomi, dan lingkungan diperlukan penelitian prospektif.

\section{Kesimpulan}

Keterlambatan atau gangguan perkembangan bicara menjadi keluhan terbanyak yang ditemukan pada keterlambatan perkembangan umum tanpa penyakit penyerta di Klinik Khusus Tumbuh Kembang RSAB Harapan Kita. Sebagai dokter spesialis anak yang sudah mengetahui tahapan perkembangan anak normal tentunya tidak akan langsung mendiagnosis gangguan perkembangan tertentu pada anak sebelum melakukan evaluasi. Keluhan utama orang tua terhadap perkembangan anak harus dicermati dan ditindak lanjuti, dan penting dalam identifikasi keterlambatan atau gangguan perkembangan anak, sehingga stimulasi dan atau intervensi dini dapat dilakukan sesuai dengan keterlambatan atau gangguan perkembangan yang dialami.

\section{Daftar pustaka}

1. Shevell M, Ashwal S, Donley D. Practice parameter: Evaluation of the child with global developmental delay. Neurology 2003;60:367-80.

2. Tervo RC, Asis M. Parents's reports predict abnormal investigations in global development delay. Clinical pediatrics 2009;48: 513-21.

3. Global Development Delay Evaluation: Evidence-based approach. Diunduh dari: http://pedclerk.bsd.uchicago.edul devdelay.html. Diakses tanggal 18 Agustus 2010.

4. Shevell M, Manjnemer A, Platt R, Webster R, Birnbaum R. Developmental and functional outcomes at school age of preschool children with global developmental delay. J child neurology 2005;20: 648-54.

5. Riou E, Ghosh S, Francoeur E, Shevell M. Global developmental delay and its relationship to cognitive skills. Developmental medicine and child neurology 2009;51: 600-6.

6. Tang KML, Chen TYK, Lau VWY, Wu MMF. Cognitive outcome of children with developmental delay in Hongkong. Diunduh dari: http://hkjpaed.org/details. asp?id=6620show=12. Diakses tanggal 18 Agustus 2010 .

7. Shevell M, Majnnmer A, Rosenbaum P, Abrahamowicz M. Profile of referrals for early childhood developmental delay to ambulatory subspecialty clinics. J child neurology 2001; 9: 645-50.

8. Delgado CEF, Vagi SJ, Scott K. Identification of early risk factors for developmental delay. Exceptionality 2007;15: 119-36.

9. Suryawan I, Narendra M. Penyimpangan tumbuh kembang anak. Diunduh dari : http://pediatrik.com/ pkb/061022022956-57x6138.pdf. Diakses tanggal 18 Agustus 2010.

10. Analisis dan evaluasi hasil survey penduduk antar sensus tahun 2005. Diunduh dari: http://www.bkkbn.go.id/Webs/ upload/infoprogram/Narasi_SUPAS2005.pdf. Diakses tanggal 18 Agustus 2010.

11. Chapman DA, Scott KG, Mason CA. Early risk factors for mental retardation: role of maternal age and maternal education. Am J Ment retard 2002;107:46-59.

12. Ramey SL, Ramey CT. Early experience and early intervention for children at risk for developmental delay and mental retardation. Mental retardation and developmental disabilities 1999;5:1-10.

13. Leung AKC, Kao CP. Evaluation and management of the child with speech delay. Diunduh dari: http://www. aafp.orglafp/990600ap/3121.html/. Diakses tanggal 3 Maret 2011.

14. Downey D, Mraz R, Knott J. Diagnosis and evaluation of children who are not talking. Infant and young children 2002;15: 38-48.

15. Glascoe F. It's not what it seems the relationship between parents' concerns and children with global delays. Clin Pediatr 1994;292-6.

16. Chen IC, Lee HC, Yeh GC, Lai CH, Chen SC. The relationship between parental concerns and professional assessment in developmental delay in infants and children. J Chin med assoc 2004;67:239-44. 